\title{
The distribution of hepatitis C virus genotypes in patients with hepatocellular carcinoma
}

\author{
Ayfer Bakir', Nuran Karabulut', Sema Alacam¹, Baris Bakir², Ali Agacfidan'1 \\ ${ }^{1}$ Istanbul University, Istanbul Faculty of Medicine, Department of Medical Microbiology, Division of Virology and \\ Fundamental Immunology, Istanbul, Turkey, ${ }^{2}$ Istanbul University, Istanbul Faculty of Medicine, Department of \\ Radiology, Istanbul, Turkey
}

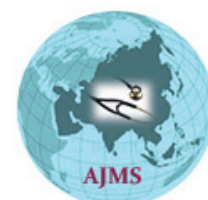

A B S T R A C T

Background: Hepatic cirrhosis develops within 20-30 years in approximately $20 \%$ of individuals chronically infected with hepatitis $\mathrm{C}$ virus (HCV). Aims and Objective: This study aimed to determine the distribution of HCV genotypes in patients with HCV-associated HCC in our region and thus to contribute to the epidemiology of HCV. Materials and Methods: HCC patients referred to the virology laboratory for HCV genotype identification between January 2013 and April 2018 were included in this study. Genotyping of HCV was performed by a commercial reverse hybridization line probe-based assay. Results: Seventeen patients who were diagnosed with $\mathrm{HCC}$ and whose HCV genotypes were analyzed were included in this study. Genotype 1 was detected in all 17 patients with HCC. When evaluating subtypes of genotype 1, genotype $1 \mathrm{~b}$ was detected in 16 (94\%) of the patients. The HCV subtyping in one patient $(6 \%)$ could not be performed. Conclusion: As a result, genotype $1 \mathrm{~b}$, one of the major risk factors for HCC, was detected in $94 \%$ of the patients included in this study. This study, consistent with the literature, shows a high association between the development of $\mathrm{HCC}$ and genotype $1 \mathrm{~b}$ in patients with chronic HCV.

Key words: HCV; HCV genotype; Hepatocellular carcinoma

\section{INTRODUCTION}

Hepatitis $\mathrm{C}$ virus (HCV) is a single-strand positive polarity RNA virus encoding a single long polyprotein belonging to the genus Hepacivirus of thefamily Flaviviridae. ${ }^{1}$ Nowadays, more than 170 million people, $2.5 \%$ of the world population, are chronically infected with $\mathrm{HCV}^{2}$ Seroprevalence rates differ according to geographical locations. It is reported the seroprevalence rate is $0.9-6.0 \%$ in East, West and South Africa, 1.1$5-8 \%$ in Asia, 2.7\% in North Africa and Middle East, $1.2-2.7 \%$ in America, $0.9-3.1 \%$ in Europe and $1.8 \%$ in Australia. $^{3}$

According to the phylogenetic analysis of genome sequences, 7 main genotypes were identified, 67 of which were approved and 20 of which were transient subtypes. ${ }^{4}$ Accurate identification of the HCV genotype is important for evaluating the epidemiological status of
HCV infection and selecting the most suitable antiviral regimen. ${ }^{5}$

Hepatocellular carcinoma (HCC) is the most serious complication of chronic liver disease and the most common cause of death in patients with compensated cirrhosis. $^{6}$

HCV genotypes show different geographical distribution. While HCV genotypes 1, 2 and 3 have widespread global distribution, genotypes 4, 5 and 6 are only seen in certain regions. Globally, while the prevalence of genotype 1 , which is the most common genotype worldwide, is $49.1 \%$, that of genotype 3 is $17.9 \%$, that of genotype 4 is $16.8 \%$, that of genotype 2 is $11 \%$ and that of genotypes 5 and 6 is $5 \%{ }^{3}$

Genotype 4 is more common in Middle East and North Africa, genotype 5 in South Africa, and genotype 6 in South China and South East Asia. Genotype 7 is only reported in Central Africa. ${ }^{5,7,8}$ 
The prevalence of sub-genotypes of HCV genotype 1, 2 and 3 also differ according to the geographical regions. While HCV sub-genotypes $1 \mathrm{a}$ and $1 \mathrm{~b}$ are most common in North America, Europe and Japan, genotype 2 is common in West Africa, South America and some regions of Italy and genotype $3 \mathrm{a}$ which is very common among intravenous drug addicts is mainly common in Europe, USA and South East Europe. ${ }^{9}$

The prevalence of HCV genotypes in Europe shows regional differences. The prevalence of genotype 1 in Europe is between $55.1 \%$ and $70 \%$, that of genotype 3 is between $21 \%$ and $29 \%$, that of genotype 2 is between $3.2 \%$ and $8.9 \%$, and that of genotype 4 is between $4.9 \%$ and $5.8 \%$. The prevalence of genotype 5 is reported to be quite low with a rate of $0.2 \%$ in West Europe and $0.1 \%$ in Middle and West Europe. ${ }^{3}$

Acute and chronic infection due to HCV is mostly asymptomatic. After acute HCV infection, $85-88 \%$ of the patients progress to chronic HCV infection and spontaneous resolution occurs in $12-15 \%$ of the patients. The rate of development of HCC was found to be $9 \%$ in the course of the disease in $75-81 \%$ of the patients with chronic HCV infection, while the rate of HCC development was $7-15 \%$ in patients with cirrhosis. The duration of chronic infection between HCV infection and cancer development is more than 2-3 decades. ${ }^{10,11}$

The main hypothesis on the development of HCV-related cancer is that it is related to inflammation, oxidative stress and hepatocellular damage due to its chronic effects. ${ }^{12,13}$

As a result, the resulting hepatic fibrosis increases the risk of HCC, simultaneously induces malignant transformation of infected cells and keeps becoming the main pathogenesis mechanism for HCC development. ${ }^{14,15}$

Factors such as age, male gender, genotype, obesity, HIV coinfection, advanced fibrosis and cirrhosis, excessive alcohol consumption, diabetes mellitus and HBV co-infection are considered as factors that increase the risk of HCC in patients with chronic hepatitis C. ${ }^{16,17,18}$ The role of HCV genotypes in the development of HCC has become the subject of many studies. Although it was reported that the risk for developing HCC in patients infected with HCV genotype $1 \mathrm{~b}$ was higher than in other genotypes, there has not been a consensus yet. ${ }^{19}$

Although the etiology of chronic hepatitis B infection remains the most common risk factor for HCC worldwide, HCV has become a major cause of chronic liver disease in both Western and Asia Pacific regions following a successful vaccination program against $H B V .{ }^{12}$ In contrast to $\mathrm{HBV}$ infection, the treatment of chronic HCV infection plays an important role in the prevention of HCV-associated $\mathrm{HCC}$ as it does not have a vaccine against $\mathrm{HCV}$ infection. ${ }^{20}$

This study aimed to determine the distribution of HCV genotypes in patients with HCV-associated HCC in our region and thus to contribute to the epidemiology of HCV.

\section{MATERIALS AND METHODS}

Seventeen patients whose plasma samples with the diagnosis of chronic hepatitis $\mathrm{C}$ were analysed for $\mathrm{HCV}$ genotype at Istanbul University, Faculty of Medicine, Department of Medical Microbiology, Division of Virology and Fundamental Immunology between January 2013 and April 2018 and who were diagnosed with HCC with abdominal computed tomography (CT) or abdominal magnetic resonance imaging (MRI) method in clinical follow-ups in radiology department were included in this retrospective study.

HCV RNA extraction was performed in the plasma samples using Qiagen (Germany) extraction kit according to the manufacturer's recommendations. The product obtained after extraction of cDNA and PCR reaction underwent a single-stage reverse transcriptase PCR (RT-PCR) by using the AMPLYQUALITY HCV-PM Bio kit (AB Analitica, Italy). PCR process was performed by using biotin labelled primers selected from the wellprotected 5' untranslated region of the HCV gene. Agarose gel electrophoresis was performed to determine the amplified PCR products. The genotyping of HCV was performed by using a kit (AMPLIQUALITY HCV$\mathrm{TS}, \mathrm{AB}$ Analitica, Italy) based on reverse hybridization with genotype specific oligonucleotide probes fixed on membrane strips. With this analysis method, six main HCV genotypes (genotype 1,2, 3, 4, 5, and 6) and major HCV subtypes (subtype 1a, 1b, 1a/1b, 2a/2c, 2b, 3a, 4a, 5a, 6a or $6 \mathrm{~b})$ can be identified.This study was performed with the approval of the Non-Interventional Clinical Research Ethical Committee of Istanbul University (reference number: 2018/855/11).

\section{Analysis}

Data analysis was performed using SPSS 25 (SPSS Inc, Chicago, IL, USA) program. The normal distribution of variables was examined by visual methods (histogram and probability graphs) and Kolmogorov-Smirnov test. The variables were compared by Student's T test or Mann-Whitney U test. Qualitative variables were compared by Pearson Chi-Square or Fisher exact tests. $\mathrm{p}<0.05$ was considered as statistically significant. 


\section{RESULTS}

Seventeen patients with HCC, whose HCV genotypes were analyzed, were included in this study. Median age of patients with HCC, consisting of nine $(53 \%)$ men and eight $(47 \%)$ women, was 67 (range $=38-76)$. Median age of male patients was $62($ range $=42-80)$ and thatof female patients was $70($ range $=38-79)$ $(\mathrm{p}=0.34)($ Figure 1$)$.

Most (44\%; 4/9) of the male patients with HCC were in the age group of $60-70$ and the female patients $(50 \% ; 4 / 8)$ were in the age group of $>70(p=0.59)$ (Figure 2). Median value of HCV RNA viral load was $731112 \mathrm{IU} / \mathrm{mL}$.

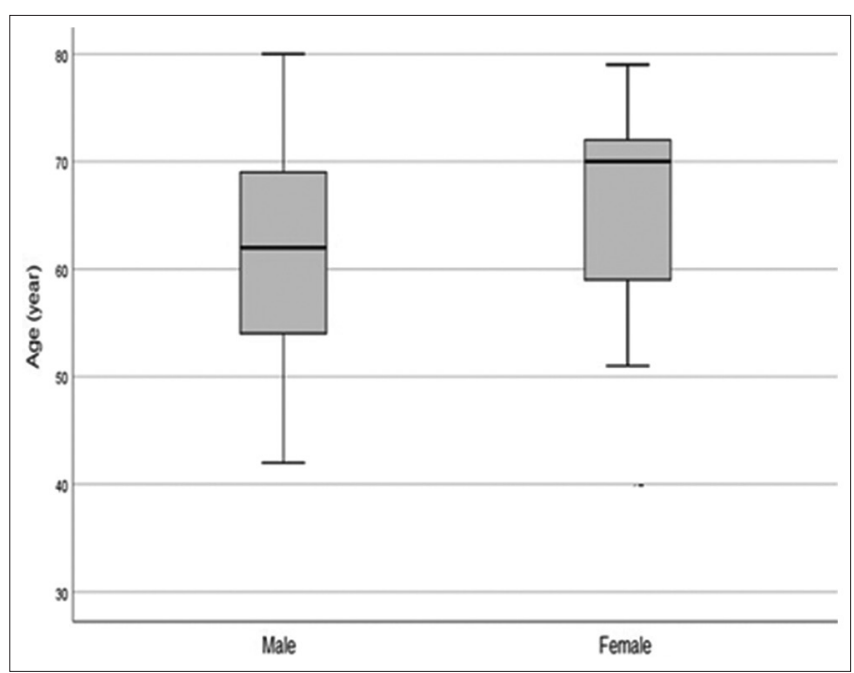

Figure 1: Median age distribution of male and female patients with HCC (Box plot)

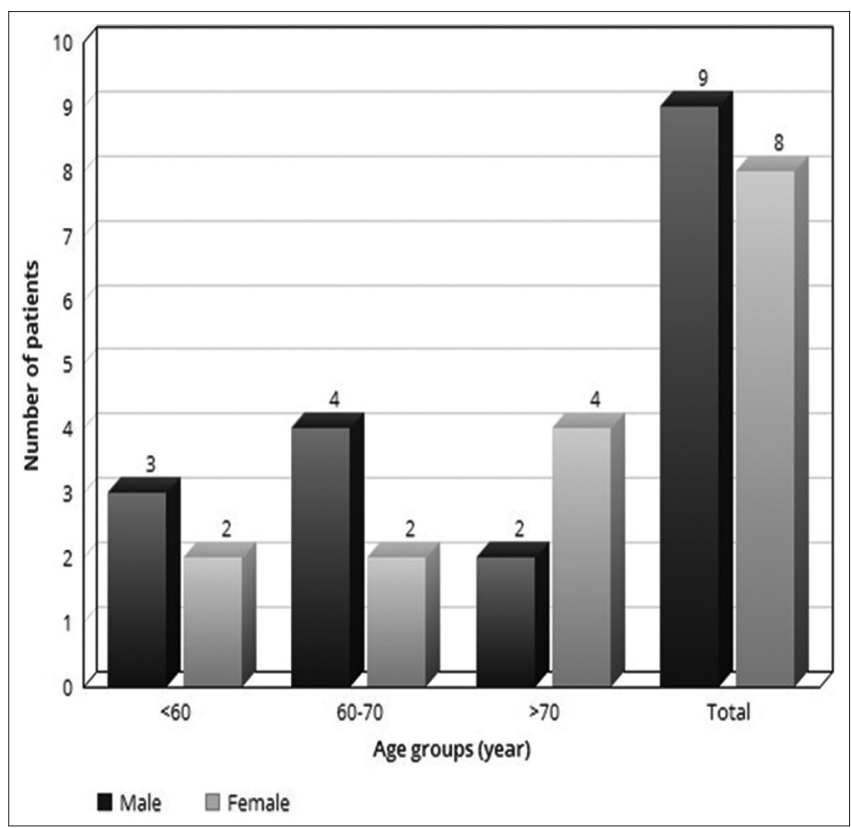

Figure 2: Distribution of patients with HCC according to the age groups
Genotype 1 was detected in 17 patients with HCC. In terms of subtypes of genotype 1; genotype $1 \mathrm{~b}$ was detected in 16 patients $(94 \%)$. The subtype could not be determinedin one patient $(6 \%)$.

\section{DISCUSSION}

HCC is the most common primary malignancy of the liver. More than 500.000 new HCC cases are identified in the world annually. HCC is the fifth most common cancer in men and seventh in women. It is the second leading cause of cancer-related deaths in the world. ${ }^{15}$

International Agency for Research on Cancer (IARC) divided some infectious pathogens into 4 groups according to their carcinogenic evidence in people: Group 1 (high carcinogenic evidence in people), group $2 \mathrm{~A}$ (probability of carcinogenic effect), group 2B (low carcinogenic effect) and group 3 (no enough carcinogenic evidence). While both HBV and HCV are included in IARC group 1, HDV is included in group 3. Although the contribution of HDV to the development of HCC on HBV could not be clearly revealed, it was asserted that the risk of HCC in the superinfection of $\mathrm{HBV}$ and $\mathrm{HDV}$ was higher. ${ }^{20}$

HCV is responsible for $27 \%$ of cirrhosis cases and $25 \%$ of HCC cases worldwide. According to the results of 6754 studies in 2015, the prevalence of Global HCV viremia was reported to be $1 \%$ and approximately 71.1 million viremic patients. Molecular studies have shown that genotypes 1, 2 and 3 are predominant HCV genotypes worldwide. ${ }^{22}$

In the same study, the prevalence of HCV viremia for our country was reported to be $0.6 \%$, while the most common genotypes were genotype $1 \mathrm{~b}$ at a rate of $80.4 \%$, genotype $1 \mathrm{a}$ at a rate of $12.9 \%$, genotype 3 at a rate of $3.7 \%$, genotype 2 at a rate of $1.5 \%$ and genotype 4 at a rate of $2.4 \%$. In this study, our country has been evaluated in North Africa and Middle East countries. However, it is observed that genotype distribution is similar to that of European countries. ${ }^{22}$

Risk factors for the development of HCC in chronic $\mathrm{HCV}$ infection include viral genotypes. Some HCV viral genotypes are associated with higher HCC risk. In a large cohort study in America, genotype 3 was reported to be associated with higher rates of HCC than genotype $1 .^{23}$

In a study conducted in France, patients with HCC were retrospectively screened between 1994 and 2007. The rate of the development of HCC within 5 years between genotype 3 and non-genotype 3 groups was investigated. The incidence of HCC was $34 \%$ for genotype 3 and $17 \%$ for others and there was statistically significant 
difference between these groups. Liver steatosis is the main histopathological feature of HCV genotype 3 infection. Steatosis is known to contribute to the development of HCC. ${ }^{24}$

In a study in the United States, $92 \%$ of 48 HCC patients have been reported to have genotype $1 .{ }^{25}$

Although less detected in developed countries, HCV genotype 6 has been shown to pose an increased risk for HCC development. ${ }^{26}$

In a study conducted in Italy, it was reported that 22 of 101 patients with chronic HCV who were followed-up for 5-7 years developed HCC. Of the patients with HCC, 19 had type $1 \mathrm{~b}$ and 3 had type $2 \mathrm{a} / \mathrm{c}$ infection, and they weremainly male and over 60 years of age. ${ }^{27}$

In this retrospective study, genotype 1 was detected in all 17 patients with HCC and genotype 1b was detected in $94 \%$ of the patients. HCV genotype studies in our country usually involve chronic HCV patients rather than HCV-associated HCC patients. In different studies conducted on HCV genotype in our country, genotype 1 has been reported to be dominant. ${ }^{28,29,30}$

It has been reported in literature that genotype $1 \mathrm{~b}$ is an independent risk factor for chronic inflammation, liver cell necrosis, fibrosis and HCC. Because the response of HCV genotype $1 \mathrm{~b}$ to interferon was lower than that of genotypes 2 and 3 , it was thought to be associated with higher rates of cirrhosis and HCC. ${ }^{17}$

Although genotype 1 is the dominant HCV genotype in our country, studies on the distribution of genotypes in HCC patients will enable the evaluation of HCC risks of rare genotypes. It is reported in literature that the rate of HCC development in the cirrhotic period is higher than in the early stages of fibrosis. However, in some meta-analysis studies, the risk of HCC was higher in the early stages of liver disease. It has been suggested that the specific conformational characteristics of the secondary structure of N-terminal of the NS3 protein characterizing HCV $1 \mathrm{~b}$ strains contribute to the increase in the risk of HCC associated with this genotype. ${ }^{17,31}$

As the study was planned only as a laboratory study, other risk factors of the patients could not be evaluated.

For all populations, a higher rate of risk is reported in men for HCC. Usually the male/female ratio is between 2:1 and 4:1. Countries with the lowest sex rates for HCC were reported as follows: 1.4/1 in Poland and Brazil, 1.9/1 in Sweden and the UK, 1.7/1 in Turkey and 0.7/1 in Iran. ${ }^{32}$
In this study, male/female ratio was found as $1.13 / 1$ in 17 patients with HCC. The fact that the male gender ratio is not significantly high may be related to the low number of patients included in the study, and therefore, more extensive studies are needed.

\section{CONCLUSION}

HCV genotype $1 \mathrm{~b}$ increases the risk of HCC development. Patients infected with HCV genotype 1b should be closely monitored for HCC.

\section{REFERENCES}

1. Smith DB, Becher P, Bukh J, Gould EA, Meyers G, Monath $\mathrm{T}$, et al. Proposed update to the taxonomy of the genera Hepacivirus and Pegivirus within the Flaviviridae family. J Gen Virol 2016;97(11):2894-2907.

2. Petruziello A. Epidemiology of Hepatitis B Virus (HBV) and Hepatitis C Virus (HCV) Related Hepatocellular Carcinoma. Open Virol J 2018;12(Suppl-1, M3:26-32.

3. Petruzziello A, Marigliano S, Loquercio G, Cozzolino A and Cacciapuoti C. Global epidemiology of hepatitis $C$ virus infection: An up-date of the distribution and circulation of hepatitis $C$ virus genotypes. World J Gastroenterol 2016; 22(34):7824-7840.

4. Chen Y, Yu C, Yin X, Guo X, Wu S and Hou J. Hepatitis C virus genotypes and subtypes circulating in Mainland China. Emerg Microbes Infect 2017;6(11):e95.

5. Aceijas $C$ and Rhodes T. Global estimates of prevalence of $\mathrm{HCV}$ infection among injecting drug users. Int J Drug Policy 2007;18(5):352-358.

6. Benvegnù L, Gios M, Boccato $S$ and Alberti A. Natural history of compensated viral cirrhosis: a prospective study on the incidence and hierarchy of major complications. Gut 2004;53(5):744-749.

7. Fu Y, Wang Y, Xia W, Pybus OG, Qin W, Lu L, et al. New trends of HCV infection in China revealed by genetic analysis of viral sequences determinedfrom first-time volunteer blood donors. J Viral Hepat 2011;18(1):42-52.

8. Murphy DG, Sablon E, Chamberland J, Fournier E, Dandavino R and Tremblay CL. Hepatitis $C$ virus genotype 7 , a new genotype originating from central Africa. J Clin Microbiol 2015;53(3): 967-972.

9. Petruzziello A, Sabatino R, Loquercio G, Guzzo A, Di Capua L, Labonia $F$, et al. Nine-year distribution pattern of hepatitis $\mathrm{C}$ virus (HCV) genotypes in Southern Italy. PLoS One 2019;14(4):e0212033.

10. Khan A, Tanaka Y, Azam Z, Abbas Z, Kurbanov F, Saleem U, et al. Epidemic spread of hepatitis $C$ virus genotype $3 a$ and relation to highincidence of hepatocellular carcinoma in Pakistan. J Med Virol 2009;81(7):1189-1197.

11. Kwon JH and Bae SH. Current status and clinical course of hepatitis C virus in Korea. Korean J Gastroenterol 2008;51(6):360-367.

12. Kim MN, Kim BK and Han KH. Hepatocellular carcinoma in patients with chronic hepatitis $C$ virus infection in the Asia-Pacific region. J Gastroenterol 2013;48(6):681-688.

13. Akuta N, Suzuki F, Kawamura $Y$, Yatsuji $H$, Sezaki $H$, Suzuki $Y$, et al. Amino acid substitutions inthe hepatitis $C$ virus core region are the important predictor ofhepatocarcinogenesis. Hepatology 2007;46:1357-1364

14. Levrero M. Viral hepatitis and liver cancer: the case of hepatitis $C$. 
Oncogene 2006;25(27):3834-3847.

15. Mittal S and El-Serag HB. Epidemiology of hepatocellular carcinoma: consider the population. J Clin Gastroenterol 2013;47 Suppl: S2-S6.

16. Fattovich G, Giustina G, Degos F, Tremolada F, Diodati G, Almasio $P$, et al. Morbidity and mortality in compensated cirrhosis type C: a retrospectivefollow-up study of 384 patients. Gastroenterology 1997;112(2):463-472.

17. Raimondi S, Bruno S, Mondelli MU and Maisonneuve P. Hepatitis $\mathrm{C}$ virus genotype $1 \mathrm{~b}$ as a risk factor for hepatocellular carcinoma development: a meta-analysis. J Hepatol 2009; 50(6): 1142-1154.

18. Lee SS, Kim CY, Kim BR, Cha RR, Kim WS, Kim JJ, et al. Hepatitis C virus genotype 3 was associated with thedevelopment of hepatocellular carcinoma in Korea. J Viral Hepat 2019;26(4):459-465.

19. Petruzziello A, Marigliano S, Loquercio G, Coppola N, Piccirillo M, Leongito M, et al. Hepatitis C Virus (HCV) genotypes distribution among hepatocellular carcinoma patients in Southern Italy: A three year retrospective study. Infectious Agents and Cancer 2017;12(1), [52].

20. Masuzaki R, Tateishi R, Yoshida H, Goto E, Sato T, Ohki T, et al. Prospective riskassessment for hepatocellular carcinoma development in patients with chronichepatitis $C$ by transient elastography. Hepatology 2009;49(6):1954-1961.

21. Romeo R, Petruzziello A, Pecheur El, Facchetti F, Perbellini R, Galmozzi E, et al. Hepatitis delta virus and hepatocellular carcinoma: an update. Epidemiol Infect 2018;146(13):1612-1618.

22. Polaris Observatory HCV Collaborators. Global prevalence and genotype distribution of hepatitis $C$ virus infection in 2015: a modelling study. Lancet Gastroenterol Hepatol 2017; 2(3):161-176.

23. Kanwal F, Kramer JR, Ilyas J, Duan Z and El-Serag HB. HCV genotype 3 is associated with an increased risk of cirrhosis and hepatocellular cancer in a national sample of U.S. Veterans with HCV. Hepatology 2014;60(1):98-105.

24. Nkontchou G, Ziol M, Aout M, Lhabadie M, Baazia Y, MahmoudiA, et al. HCV genotype 3 is associated with a higher hepatocellular carcinomaincidence in patients with ongoing viral $\mathrm{C}$ cirrhosis. J Viral Hepat 2011;18(10):e516-22.

25. Lok AS, Seeff LB, Morgan TR, di Bisceglie AM, Sterling RK, Curto TM, et al. HALT-C Trial Group. Incidence of hepatocellular carcinoma and associated riskfactors in hepatitis C-related advanced liver disease. Gastroenterology 2009; 136(1):138-148.

26. Lee MH, Hsiao TI, Subramaniam SR, Le AK, Vu VD, Trinh HN, et al. HCV Genotype 6 Increased the Risk for Hepatocellular Carcinoma Among Asian Patients With Liver Cirrhosis. Am J Gastroenterol 2017;112(7):1111-1119.

27. Bruno S, Silini E, Crosignani A, Borzio F, Leandro G, Bono F, et al. Hepatitis $C$ virus genotypes and risk ofhepatocellular carcinoma in cirrhosis: a prospective study. Hepatology 1997;25(3):754-758.

28. Karslıgil T, Savaş E and Savaş MC. Hepatit C Virusu Genotip Dağılımı ve 5'UTR Nükleotid Değişiklikleri. Balkan Med J $2011 ; 28(3): 232-236$.

29. Kayman T, Karakükçü Ç, Karaman $A$ and Gözütok F. Kayseri bölgesinde hepatit $C$ virüs enfeksiyonunun genotip dağılımı.Türk Mikrobiyol Cem Derg 2012;42(1):21-26.

30. Çekin $Y$, Gür N, Çekin AH, Altuğlu İ and Sertöz RY. Antalya Eğitim ve Araştırma Hastanesinde kronik Hepatit $C$ hastalarının genotip dağılımının araştırılması. Mikrobiyol Bul 2014;48(3): 484-490.

31. Nishise $Y$, Saito T, Sugahara K, Ito JI, Saito K, Togashi $H$, et al. Risk of hepatocellular carcinoma and secondary structure ofhepatitis C virus (HCV) NS3 protein amino-terminus, in patients infected with HCVsubtype 1b. J Infect Dis 2007; 196(7): 1006-1009.

32. El-Serag HB. Epidemiology of viral hepatitis and hepatocellular carcinoma. Gastroenterology 2012;142(6):1264-1273.

\footnotetext{
Authors Contribution:

AB- Concept and design of the study, manuscript preparation, interpreted, NK- Concept and design of the study, statistically analyzed and interpreted:

SA-Concept and design of the study, interpreted; BB- Concept and design of the study, AA-Critical revision of the manuscript.

Work attributed to:

Faculty of Medicine, Istanbul University, Istanbul, Turkey.

Orcid ID:

Dr. Ayfer Bakir - (D) http://orcid.org/0000-0002-9006-5267

Dr. Nuran Karabulut - (D) http://orcid org/0000-0003-3550-2599

Dr. Sema Alacam - (D) http://orcid.org/0000-0001-7957-2906

Assoc. Prof. Dr. Baris Bakir - (1) http://orcid.org/0000-0002-6587-9787

Prof. Dr. Ali Agacfidan - (1) http://orcid.org/0000-0002-5470-296X

Source of Support: This piece of research work has been funded by University Grant Commission, Bhaktapur, Nepal. Conflict of Interest: The authors share no conflict of interest in research article submitted.

Declaration: The manuscript has not been published elsewhere. This study has not been supported by any organization. All authors have not real or perceived conflicts of interest. Ethical approvals were obtained from Ethics Committee of Istanbul Faculty of Medicine (reference number 2018/11/855). That all authors have seen and approved the content of the manuscript and have contributed significantly to the work.
} 